\title{
Graham Smith (1953-99): an appreciation
}

Graham Smith died on 23 April. He was 46 years old, and had been suffering for some time with undetected carcinomas, only discovered during his brief spell in hospital preceding his death. At this time, his love and regrets were for his wife, Marilyn, his son, Alex, and other members of his family. His pride and content with his academic work were both evident and justified.

Graham was a political geographer of the Soviet Union and its successor states. His graduate research, at the University of Glasgow's renowned Institute of Soviet and East European Studies, jointly supervised by the geographer Ronan Paddison and the historian James White, was about the dialectical relations between Latvian nationalism and the spatial organization of Latvian society (1978). Graham presented nineteenthcentury modernization as a fundamentally spatial process of labour migration and commercialization that corroded local loyalties, creating for the majority of the people an unprecedented opportunity to feel part of something much broader (1979a). He argued that the modernity of nationalism was the historical reality that nationalist ideologies denied. Graham viewed nationalism as both a spatial ideology and a spatial practice. He described how Latvian nationalism projected an image of a traditional rural society based on dispersed, self-sufficient peasant households, which was continually under threat from urban, commercial society and its agents, the Baltic German landowners and merchants. The independent Latvian state of the 1920s and 1930s broke up larger rural villages and expropriated large farms, redistributing them to the native peasantry. Latvian nationalists sought to recreate national space in the ideological image that had been their consolation against the social tensions of earlier modernization. Graham went on to examine how, after the Second World War, the Soviet government tried to reshape the ideal and material geographies of Latvia to promote a new Soviet identity. However, exceptionally, the peasants of Latvia were not driven into villages upon the collectivization of their land. They remained in their dispersed farmsteads. Rather, Stalin sought to create a new Soviet class by the promotion of urban heavy industry and the immigration of Russian skilled labour. In the period 1957-59, when Latvian planners gained some control over economic planning, they demonstrated their dissatisfaction with Russification by downplaying heavy industry in order to stem immigration. Yet Graham also argued that there was clear evidence (from patterns of intermarriage and the Latvian ascription of the children of mixed marriages) that Russian settlers were slowly becoming Latvianized (1982). These distinctive features of Soviet economic development, then, meant that further modernization in Latvia was not eroding national identities as some versions of modernization theory would suggest (1984).

This insistence on the contextual rootedness of nationalism in particular ideal and material forms of spatial organization is a recurring theme in Graham's work. It stands as a rebuke to all forms of primordialism in nationalist myths. It also stands as a challenge to political geographers, for they have the responsibility, as well as the opportunity, of responding to these topical issues, and Graham's own interest in nationalism was, at least in part, fuelled by his deeply ambivalent feelings about Scots nationalism.

In 1979, Graham moved to England to a temporary lectureship at the Cambridge College of Arts and Technology (now Anglia Polytechnic University). He now added an enthusiasm for teaching to his earlier passion for research. In 1981, Graham was appointed as lecturer in the Department of Geography and fellow of Sidney Sussex College at the University of Cambridge. Although some aspects of academic life at Cambridge by turns amused and infuriated him, and he came to resent the lack of promotions, there is no doubt that he loved teaching the graduate and undergraduate students who relished his enthusiasm. He also enjoyed the company of colleagues who shared his research enthusiasms and passion for talking and writing about geography. Graham believed that geographers had a great deal to say about the big issues of current affairs if they only developed their theories in an interdisciplinary manner and paid close attention to the empirical detail of their world. Many of his former students will confirm that this combination of passion and scholarship made his lectures informative and provocative, even inspirational. 


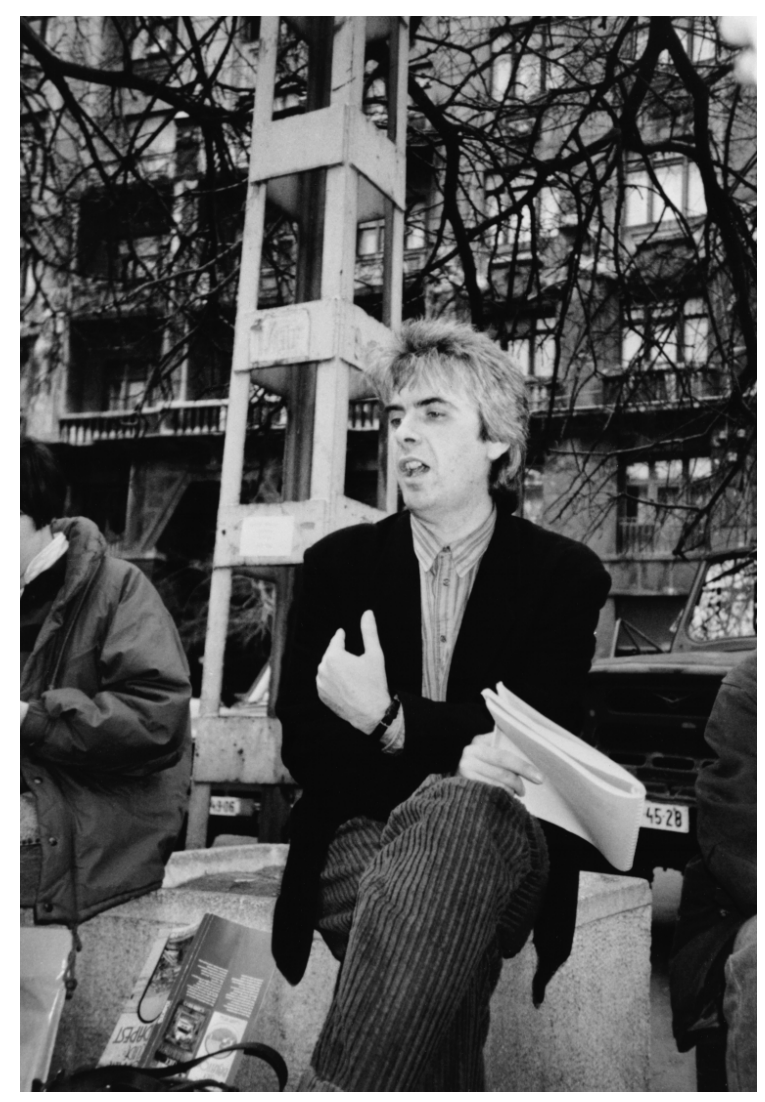

Graham believed that political geographers were ignoring some of the central geographical issues of the day. An overemphasis on the spaces of the administrative state had meant that the 1950s and 1960s had seen too little work on the spaces of the demotic nation (1979b) or even on politics itself as a field of conflict and negotiation (1983). In the early 1980s, Graham was delighted to see geographers working on the different scales of state, and using theories, such as those of Marx and Wallerstein, that recognized the central importance of social conflict. Yet he thought it absurd that Marxist and world-systems theorists failed to acknowledge the distinctiveness of the socialist world and he worried that their structuralist explanations leaned so heavily upon economic factors that they explained away politics altogether. In ignoring the special characteristics of socialist territoriality and economy, world systems theorists were in danger of repeating the 'generalising impulse of spatial science' (1989a, 322). Graham felt that, in its economism, world systems theory provided no coherent way of understanding the place of power-blocs in world geopolitics (1994a, 54-77). By treating the world as a coherent system defined by a single essence (global capitalism), world systems theory seemed fated to treat all oppositional movements as antisystemic in exactly the same way and thus as having the same basic anti-capitalist intentions. On this view, the collapse of socialist economies in Eastern Europe was brought about by antisystemic, anti-capitalist popular movements. Graham thought this explanation ridiculous and preferred to take those popular movements at their word; they were in favour of introducing private enterprise into command economies (1993).

If political geographers were to look carefully at their world and produce more nuanced geographical insights, they would need to develop their conceptual frameworks beyond the heritage of geopolitics and the functional school (1981). Graham agreed with Derek Gregory that 
geographers should pay more attention to social theory, but he placed greater stress on political geographers' want of sufficient familiarity with political theory:

For the greater part of its development, the subject dwelled introspectively within the confines of the geographical fold; research in the field was accomplished by and for geographers who took little cognisance of thinking in the mainstream political and social sciences and attracted no interest from beyond their disciplinary frontiers. $(1983,1)$

Graham argued for theoretical eclecticism, with different theories being used to explain different aspects of the relations between space and politics. $\mathrm{He}$ also believed that theoretically informed empirical inquiry was the best way of improving both theory and our understanding of the world. Graham promised to open up

post-Soviet studies to more recent developments in political and social theory while at the same time grounding such explorations in solid, empirical enquiry. (1999a, 1-2)

In terms of methodology, Graham argued that empirical work used theory most productively when it illuminated both the general and the more specific features of any particular case through comparative study. The geographical framework of The post-Soviet states, his recent book published posthumously, is shaped by an attention to 'both comparative and geopolitical theories of transition in helping us to understand the nature of and prospects for the post-Soviet transition' (1999a, 13).

Pressing geographical issues, political theory, empirical research and a comparative approach shaped Graham's political geography and he pursued it in the classroom, the study and the public sphere. With Derek Gregory and Ron Martin, he developed a first-year course in human geography at Cambridge University that set out the links between human geography on one side and social, political and economic theory on the other (1994a). For second-year students, he taught a course, 'Society, politics and space', which looked at the overlap between politics and geography, and here he developed his own analyses of such topics as nationalism (1985a; 1998), federalism (1995a), diasporas (1997a) and social justice (forthcoming). In third-year geography, he taught a course that applied these analyses to the Soviet (1989b) and post-Soviet states (1999a). He also took field classes to Budapest where he directed the attention of students to the landscapes of nationalism, ethnicity, socialism (1990a) and the Holocaust (1994b; 1995b). He was an attentive, supportive and stimulating supervisor of $\mathrm{PhD}$ students on topics relating to the political, cultural and economic geography of central and eastern Europe and of the Soviet and post-Soviet states. Graham had enjoyed the support of shared enthusiasms as a graduate student himself and he recreated that camaraderie with his graduate students and his fellow researchers in the Baltic States Research Project which he, funded by the Institute of Peace Studies and the Leverhulme Trust, set up in the Department and in the Post-Soviet States Research Programme (the latter he had founded in Sidney Sussex College with support from the College, the Nuffield Foundation, the British Council and the Leverhulme Trust). In terms of public service, he was consultant or adviser to many bodies including the Council of Europe, the British Foreign Office, Scandinavian human rights organizations and the Organization for Security and Co-operation in Europe.

In teaching, research and public service, then, Graham advocated the value of a geographical approach for understanding the distinctive dilemmas and possibilities of the socialist states. Based on state-ownership of resources and the central planning of the economy, socialist countries pursued distinctive strategies for development that had a marked spatial dimension. Under Stalin, the Soviet Union had promoted heavy industry and rapid urbanization both to counter the 'idiocy' of rural life and to build efficiently the militaryindustrial complex that alone could protect socialism from a hostile world (1989b). After Stalin's death in 1953, the Soviet Union pursued more balanced development, with slower urbanization and an attempt to distribute economic growth more evenly across space. This tension between the efficiency of nucleated development and the equity of more dispersed development was one that Graham highlighted as a recurring theme in Soviet society. To the extent that equity was taken seriously, the Soviet Union could not, he suggested, be seen as a straightforward case of internal colonialism. Instead the federal system delivered clear benefits of investment to the poorer Central Asian republics, and in many of the ethnoregional societies the Soviet Union advanced literacy and ensured the training of a native specialist elite (1990b). This system of federal colonialism 
involved political concentration with a measure of welfare dispersal $(1989 \mathrm{c})$. For the native elites in the ethnoregional republics, a system which educated them for local administrative and scientific leadership ensured that the 'privileges of place' $(1988,184)$ bought their acquiescence and political subjugation. Those privileges depended upon a further territorial strategy whereby Soviet society saved money on social infrastructure by denying peasants the right to migrate at all and restricting many other workers to the smaller 'open' cities and peri-urban informal settlements, while keeping for diploma holders the right to live in the better-appointed 'closed' cities. This underurbanization was policed by the system of internal passports and residence permits (1990c).

Graham saw this federal system as a stabilizing force in Soviet society. It meant, he argued, that nationalist secession was not the inevitable consequence of the system of federal colonialism. Instead, regional elites might express the regional priority of squeezing resources out of central government rather than the nationalist priority of separating completely from the federal government. Nationalist mobilization was most likely to occur under the following circumstances: where there was a strong coincidence between administrative and demographic boundaries; where there was a previous history as a nation state; where there was an appropriate external reference group that was doing much better culturally and economically; and where the regional elite no longer saw the federal system as able to meet their career aspirations, or saw it as a clear economic drain, unable to deliver continued growth (1985b). Graham thought this most likely in the Baltic republics and least likely in the Central Asian republics. On the whole, though, he remained impressed with the capacity of the federal system to manage centripetal tensions: '[ $t$ ] not whether the Soviet state is about to break up; the fallacy of its imminent demise has already been well rehearsed elsewhere' (1989d, 18; referring to 1985b). But its demise was imminent and it happened in ways that this earlier work (1985b) had illuminated.

From 1985, Gorbachev's reforms destabilized the federal system and his attempt to gain Western support for his restructuring of the economy committed him to the disavowal of the routine use of force to stifle dissent. Together these moved the Soviet Union to crisis. Glasnost' began as part of a campaign to get citizens to report on economic corruption. As part of the same campaign, Gorbachev purged the regional administrators in many republics including Kazakhstan. In this case, he broke with the established procedures of the Brezhnev period and replaced a native administrator with an ethnic Russian, leading, in December 1986, to the first serious nationalist riots. This new openness was also intended to recruit a civil society for the creation of a new economy based less on state industries and more on private initiative, organized through cooperatives. The Baltic states were to be the showcase for the new policy, and public debate there was particularly unfettered (1994c). Civil society responded in precisely the way Graham had earlier sketched out (1985b). The coincidence of linguistic and administrative borders had sustained Latvian, Lithuanian and Estonian nationalism. The memory of their earlier inter-war independence encouraged them and provided grounds for a re-examination of the betrayal whereby their independence had been ended by an agreement between Hitler and Stalin. The Baltic peoples looked to Scandinavia for an image of what they might have been, both economically and culturally. Perestroika was not delivering economic growth and Russian competition for elite positions was eating into the prospects for the native specialists and intellectuals.

By 1988 the Soviet authorities in Moscow realized that a full review of their nationalities policy was called for. At this moment, Graham gathered together a group of regional experts for their own review of The nationalities question in the Soviet Union (1990d). He reviewed the evolution of the Soviet federal system, noting that Lenin had proposed it initially as a way of accommodating the reluctant peripheral nations during the constitution of the USSR in 1922. It was clearly Lenin's belief that in time such regional identities would be melded into one overarching Soviet identity and that, in this sense, the federal system was a temporary arrangement. Reviewing the pressures of the period up to the first declaration of independence, by Latvia in March 1990, Graham concluded that '[h]istory may prove Lenin right in viewing the Soviet federation as a transitional form but not in the way he envisaged' (1990d, 17). The abortive coup of August 1991 was an attempt to prevent the USSR becoming a voluntary federation and, in the aftermath of that coup, a new Commonwealth of Independent States was set up, from which the 
Baltic states and Georgia absented themselves. The Soviet Union dissolved itself on the last day of that year and Russia itself became a Russian Federation of some 89 constituent units. Here was a whole series of new political and geographical issues to which Graham could turn his attention (1996a).

As he had in his doctoral thesis, Graham continued to insist that there was nothing natural or timeless about nationalist identities. As such, it was misleading to accept nationalists at their word when they presented themselves as restoring ancient nationalist identities that had been suppressed. The new set of political and constitutional arrangements were shaped in very powerful ways by the immediate Soviet past (1995c). In writing of 'the rationality of nationalising regimes' $(1998,98)$, Graham drew attention to the immediate material benefits that were expected to flow from independence. For the native cultural elite in the Baltic states, the exclusion of Russian settlers from positions of authority, or from acquiring state assets after privatization, promised both social and economic advantage (1994a). These new states were now ethnic democracies (1996b) in which full citizenship was accorded to only a core group. Much of Graham's public service in the last few years has been concerned with stiffening the resolve of European institutions to seek amendments to these discriminatory constitutions as a condition for according the Baltic states membership of interstate associations. As he wrote to The Times,

If membership of the EU is also about furthering liberal democracy and securing good relations with its eastern neighbour, Russia, then EU countries surely need to exert further pressure on Estonia to put its own house in order before granting it membership. (22 July 1997)

He was convinced that such pressure was effective (1996c; 1997b).

Instead of being a return to past identities and arrangements, the post-Soviet states are best understood as transitions from particular types of command economies to new post-colonial, posttotalitarian and economically liberal societies. The spatial dimensions of this threefold transition are described in his last book, The post-Soviet states. Much of the book is concerned with Russia's future: how it imagines itself between Europe and Asia (1999b); why Russian ethnics in the borderland states do not seem ready to constitute themselves as a self-conscious diaspora; how democracy is threatened by the authoritarian policies that deliver privatization most abruptly and why the West should give aid to assist in more gradual transitions; how the federal system has become a matter of ongoing constitutional adjustment and why this may create a flexible system of mixed rights; and how the failure of the Russian state to promote foreign investment in the regions has promoted the development of a more disaggregated economic system in which the regions forge their own global links. Although the Soviet Union has broken up, Russia is surprisingly stable and seems set to repeat some of the federalizing territorial strategies that gave the USSR its seven-decade lifespan (1990a). As they consider these and so many of the other geographical issues of world affairs, political geographers will continue to find insight and inspiration in Graham's work, and that, after all, is the academic legacy of a truly critical and effective scholar.

Gerry Kearns

\section{Selected bibliography}

1978 The politics of Latvian nationalism Unpublished $\mathrm{PhD}$ thesis, Institute of Soviet and East European Studies, University of Glasgow

1979a The impact of modernisation on the Latvian Soviet Republic Co-existence: an International Journal 16 $145-64$

1979b Political geography and the theoretical study of the East European nation Indian Journal of Political Science $40259-83$

1981 (with Muir R) Political geography Teaching Politics 103 304-23

1982 Die Probleme des Nationalismus in den drei baltischen Sowjetrepubliken Estland, Lettland und Litauen [The nationalities problem in the Baltic Republics of Estonia, Latvia and Lithuania] Acta Baltica 21 143-77

1983 Political geography, politics and the state Social Sciences Research Journal 8 1/2 1-27

1984 Das Problem der Erhaltung der nationalen identität [The problem of the preservation of national identity] in Boettcher $\mathbf{E}$ and Nove $\mathbf{A}$ eds Die soziale und Wirtschaftliche Entwicklung der Baltsichen Nationen Westfalische Wilhelms Universistät, Munster 265-305

1985a Guest editorial: nationalism, regionalism and the state Environment and Planning C: Government and Policy $313-9$

1985b Ethnic nationalism in the Soviet Union: territory, cleavage and control Environment and Planning C: Government and Policy 31 49-73

1988 Ethnoregional societies, developed socialism and the Soviet ethnic intelligentsia in Johnston R Knight D 
and Kofman E eds Nationalism, self-determination and political geography Croom Helm, London 166-88

1989a Privilege and place in Soviet society in Gregory D and Walford $\mathbf{R}$ eds Horizons in human geography Macmillan, London 320-40

1989b Planned development in the socialist world Cambridge University Press, Cambridge

1989c Administering ethnoregional stability: the Soviet state and the nationalities question in Williams C and Kofman E eds Community conflict, partition and nationalism Routledge, London 224-51

1989d Gorbachev's greatest challenge: perestroika and the national question Political Geography Quarterly 81 7-20

1990a International groups: Comecon, dead duck or phoenix? Geo 134 14-15

1990b The Soviet federation: from corporatist to crisis politics in Chisholm $\mathbf{M}$ and Smith $\mathbf{D}$ eds Shared space: divided space: essays in conflict and territorial organisation Unwin Hyman, London 84-105

1990c The Soviet underclass Geographical Magazine 625 4-7

1990d ed The nationalities question in the Soviet Union Longman, London

1993 Ends, geopolitics and transitions in Johnston $\mathbf{R}$ ed The challenge for geography: changing world, changing discipline Blackwell, Oxford 76-99

1994a (with Gregory D and Martin R) eds Human geography: society, space and social science Macmillan, London 1994b The geography of persecution Geographical 669 22-5

1994c The Baltic states: the national self-determination of Estonia, Latvia and Lithuania Macmillan, London 121-43

1995a ed Federalism: the multi-ethnic challenge Longman, London 1995b (with Cole T) Ghettoisation and the holocaust: Budapest 1944 Journal of Historical Geography 213 300-18

1995c ¿Federalismo ruso? Centro, etno-regionalismo y transición [Whither Russian federalism? The centre, ethnoregionalism and transition] Antropologia 9 81-102

1996a ed The nationalities question in the post-Soviet states Longman, London

1996b The ethnic democracy thesis and the citizenship question in Estonia and Latvia Nationalities Papers 242 119-216

1996c When nations challenge and nations rule: Estonia and Latvia as ethnic democracies International Politics $33127-43$

1997a The Russian diaspora: identity, citizenship and homeland in Bradshaw $\mathbf{M}$ ed Geography and transition in the post-Soviet republics Wiley, Chichester 73-88

1997b (with Wilson A) Rethinking the post-Soviet Russian diaspora: the potential for political mobilisation in Eastern Ukraine and north-east Estonia EuropeAsia Studies 495 845-64

1998 (with Law V Wilson A Bohr A Allworth A) Nation-building in the post-Soviet borderlands: the politics of national identities Cambridge University Press, Cambridge

1999a The post-Soviet states: mapping the politics of transition Arnold, London

1999b The masks of Proteus: Russia, geopolitical shift and the new Eurasianism Transactions of the Institute of British Geographers 24 481-94

forthcoming Sustainable federalism, democratisation and distributive justice in Kymlicka W and Norman W eds Multicultural citizenship: theory and practice Oxford University Press, Oxford 